\title{
Adolescents' Moral Issues and Counselling Intervention on the Family Psycho-Socio Security Problems
}

\author{
Beatrice 0. Ajidahun. PhD
}

\section{Doi:10.5901/mjss.2014.v5n14p620}

\section{Abstract}

The family is very important in any society because it is the basic unit in today's society. Though small, it is playing a significant role in the country. The moral training of the adolescent child starts from the family and this is what the adolescent child exhibits outside the family. A total number of 100 parents and adolescents were sampled in Akoko East Local Government Area in Ondo State, Nigeria. The subjects were exposed to Family Security and Moral Issues Questionnaire (FSMDQ) consisting of 30 items. Four hypotheses were postulated. The data were analysed using chi-square statistics. Results showed that family consciousness, personal and rented apartments, insecurity and moral problems were all significantly related to general insecurity in Nigeria.

\section{Introduction}

The family structure, as it is today, has been influenced and affected in terms of content and context to a great extent by civilization and the technological revolution that has engulfed the world compared with the past. Everyone, irrespective of his position or status in the society comes from a family. Two families are not exactly alike and so families are unique in their functions and structures. According to Lamanna and Riedmann (2003), family is a group of persons united by the ties of marriage blood or adoption; constituting a single household; interacting and communicating with each other in their respective social roles and creating and maintaining a common culture.

In the early fifty's and late sixty's, an ideal home was where we had a father, mother and their children. Those who deviated were socially unacceptable and stigmatized today. According to Stacey (1996), there is a proliferation of different family forms; two -earners, single parents, and cohabiting, blended, gay and lesbian families. The fact still remains that the most common household types today are those of married couples who are with children.

Traditionally, nuclear and extended families have contributed a lot to families in times of help and assistance to family members. According to Casper (2000), a lot of changes had occurred in families compared to what it used to be in the past. Today, marriage cohabitation has emerged as a lifestyle intermediate between marriage and singlehood. The number of people living alone is substantial and there are more single parents households than ten years ago including a big increase in the number of single fathers. In the same manner, according to the author, some cohabitants maintain gay and lesbian domestic partnership.

According to Usdansky $(2000$,$) many adult children live with their parents. Many parents are working parents and it$ is a dramatic change to what was obtainable in the 50's where few mothers engaged in maternal employment. Statistics showed that 60.7 per cent of married mothers with children under six were employed. This implies that female single family heads who are mothers of children under six have high rate of employment. Unmarried mothers tend to give birth to more children than the married children unlike in the past. According to the author, unmarried birth rates increased six folds from 1940 to 1990 growing especially rapidly in the 1970's. More premarital pregnancies are on the increase. Estimates are that 54 percent of first births to women aged 15-29 were conceived out of wedlock in the early 1990s.

According to Whitehead and Popenoe (2001), divorce rates have stabilized although they remain at high level. It is now obvious that approximately half of marriages end in divorce. The divorce rate, according to the author, had risen slowly from the nineteenth century onward, doubled from 1965 to the end of 1970s; it has tripled and even increased in the recent time. Three quarters of divorce women remarry within ten years. There is no doubt that all these changes within the families have its impacts on the security of the families and their members. Whether families are traditional or modern in form, they create boundaries and they serve as a repository or archives of family memories and traditions.

According to Burton and Jarrett (2000), families create both physical and psychological boundaries between themselves and the rest of the world whether in multiple or single-family dwellings, families in virtually all cultures mark off some physical space that is private and theirs alone. Family values such as family togetherness, stability and loyalty focus on the family as a whole. The family is a major source of stability for everyone.

Olarewaju (2004) observes that the family is the most enduring and permanent of all groups where we derive our 
identity and fulfil the potentialities for personal growth and development. It is a fundamental social institution, which provides for rearing of children and for meeting other important human needs. In a nation, family is very central as it is the activity of respective family members that eventually bear on the society or nation as a whole. To Oyebamiji and Adekola (2008), the present economic downturn in Nigeria as a nation has affected greatly the Nigerian families in performing their duties. Many adolescents from Nigerian families are involved in a lot of criminal activities like robbery, murder, cultism, prostitution, examination malpractice and many others. These are all indications that the family might have failed in its duties of producing morally sound citizens for the society.

According to Gibbs (2003), moral development involves thoughts, behaviours and feelings regarding standards of right and wrong. Moral development has an intrapersonal dimension that is a person's basic values and sense of self and interpersonal dimension that is a focus on what people should do in their interactions with other people. Parent - child relationship is very important in moral development of an adolescent. At this stage, they reason logically, abstractly and deductively. They try to compare the real with the ideal; create contrary- to -fact-proposition. They are cognitively capable of relating the distant past to the present; understand their roles in society, in history and the universe, conceptualise their own thoughts and think about their mental constructs as objects. Adolescence period cannot be compared to the period of parent- child relationship in which parents have the power and the children do not and at this stage (pre adolescence) they are less likely to advance in moral reasoning because rules are often handed down in an authoritarian way.

Adolescents who are well brought up not to steal, kill, rob, cheat, or commit any immoral acts are sometimes faced with contradictions between the moral concepts they have accepted and experienced outside their family and neighbourhood. According to Walker and Pitts (1998), adolescents come to recognise that their set of beliefs is but one of many and that there is considerable debate about what is right and what is wrong. They start to query their former beliefs and in the process develop their own moral system.

Bandura (2002) argues that people usually do not engage in harmful conduct until they have justified the morality of their actions to themselves. In this process of moral justification, immoral conduct is made personally and socially acceptable by portraying it as serving socially worthy or moral purposes. In many instances, perpetrators of immoral acts have twisted values, norms, theology, customs and beliefs so that they see themselves as doing God's will or for fulfilling the desires of the masses. In Nigeria for instance, young people see nothing bad in robbing the government banks because they justify their actions by saying it is government money. Some say that they are graduates and they are not gainfully employed by the government. Others justify their evil actions by saying that there are pen robbers among the government officials. There are lots of reasons criminals give to justify their actions.

These moral problems have led to insecurity problems in the country and many adolescents are among the perpetrators of these immoral acts. And those who are yet to participate are having social and moral problems. Family security is a recent contemporary issue in Nigeria. According to Akowe (2012), many lives and properties had been destroyed. No one is sure who the next target will be. Terrorism, kidnapping, robbery, murder and the likes are the order of the today. Nigeria is faced with very serious security challenges. Most of the perpetrators are young people from different families. The adolescents have continued to pose threats to the society through their activities.

Security is the degree of protection against danger, damage, loss, and crime. Security as a form of protection should be structured in such a way that every member of the society will benefit from it. According to Odundayo (2001), security is all the acceptable measures taken or put in place to prevent, protect, detect and neutralise threats against a given target.

When families are not secured, it may be difficult for the values of such families to be entrenched in the children. Many families in Nigeria had witnessed lot of insecurities and this had led to a number of traumas, calamities and misfortunes. Even the government security operatives who are looked upon for the security of lives and property are sometimes victims themselves. The government security agents are totally incapable of providing the required security for the people. Obviously, the country needs to do a lot in this regard.

The counselling intervention adopted in this paper is self-management strategies and the focus will be on self efficacy. Self- efficacy is described by Bandura (1993) as a cognitive process that mediates behavioural change. Selfefficacy on the other hand is seen as a concept about how individuals' personal beliefs help them in exercising control over events in their lives. In other words, self -efficacy is an estimate of a person's skill in dealing with some problems/tasks. People with high self -efficacy recoup very quickly from failure, loss, attack, the loss of a loved one and so on.

According to Seligman (1990), those with low self -efficacy fall into a state of learned helplessness. They are plagued with depression and that contributes to pessimism, a low level of energy, negative internal dialogue, vulnerability and hopelessness. Cormier and Cormier (1998) believe that individuals enhance their self -efficacy by being competent in doing the correct things, willingness to live right and the ability to put others into consideration while performing a task. 
The degree of perceived self-efficacy, self-confidence and personal belief has their origin in the family and the environment and the cultural context in which the family resides.

The insecurity problem in Nigeria might have affected the self-efficacy of the adolescents. Many seem to have lost confidence in themselves and the nation at large. A lot of these adolescents too might have lost focus by taking to crimes to survive in life. Many of these young people are always shifting the blame to lack of employment, poverty and the likes. Many of them sometimes suffer psychologically and misbehave to please their confused minds. The counselling intervention used in this strategy means that the counsellor should train the clients on how to acquire self-efficacy (confidence) to perform the specific skills by setting goals to be achieved. Self-efficacy training involves two types of personal expectation that affects goal achievement. One is an outcome expectation and the other is an efficacy expectation. The outcome expectation has to do with whether and how much a client believes that engaging in morally accepted behaviour will eventually produce the desired results. The efficacy expectation has to do with client's level of confidence and determination to practice the acceptable behaviour necessary to yield desired results.

\section{Purpose of the Study}

The purpose of this study is to investigate the relationship between family psycho-social security and moral development of adolescents. It is also to find out how counselling intervention could correct the problem of insecurity caused by deviant adolescents in some families.

\section{Research Hypothesis}

Four research hypotheses were formulated and tested at 0.05 level of significance to verify the purpose of the research.

1. There is no significant relationship between the family psycho-social security consciousness and moral issues of adolescents.

2. There is no significant relationship between the psycho-social security of families in personal apartments and the security of families in rented apartments.

3. There is no significant relationship between the psycho-social insecurity of families and the moral problems in Nigerian situation.

4. There is no significant relationship between counselling intervention and family psycho-social moral insecurity problems.

\section{Population and Sampling Procedure}

The population consists of all families' members who are facing security problems. The families' members used were the parents and their adolescent children who were old enough to understand the concept of security. One hundred families' members were sampled from different homes in Akoko North Local Government Area of Ondo state, Nigeria.

\section{Research Instrument}

The data for the study were generated through a questionnaire titled: 'Families Security Questionnaire (FSQ)'. The questionnaire is divided into two sections. Section A contains the bio data of the families while section B contains 30 items which were used to find out the relationship between families security and moral development of the adolescents.

\section{Data Analysis}

Chi square was used to analyse this data at 0.05 level of significance.

\subsection{Hypothesis One}

This states that there is no significant relationship between family psycho-social security consciousness and moral issues of adolescents. 
Table One: Relationship between Family Psycho-social Security Consciousness and Moral Issues of Adolescents.

\begin{tabular}{|c|l|c|c|}
\hline & & \multicolumn{2}{|c|}{ RESPONSES } \\
\hline S/N & ITEMS & AGREE & DISAGREE \\
\hline 1. & Many families in Nigeria may not have security consciousness. & 77 & 23 \\
\hline 2. & A lot of homes may take the issue of their security for granted. & 93 & 07 \\
\hline 3. & Many sometimes believe that because they are poor, they do not need to be security conscious. & 86 & 16 \\
\hline 4. & The measures to determine where children go to may not be put in place by families. & 79 & 21 \\
\hline 5. & $\begin{array}{l}\text { Some parents are in the habit of sending young people on errands not minding the security of } \\
\text { the place. }\end{array}$ & 82 & 18 \\
\hline 6. & Some people believe that rented apartments are more secured than personal apartments. & 26 & 74 \\
\hline & Total & 441 & 159 \\
\hline
\end{tabular}

\begin{tabular}{|c|c|c|c|}
\hline & Average Observed Responses & df & X2c \\
\hline Agree & $73.5(50)^{\star}$ & \multirow{2}{*}{1} & \multirow{2}{*}{23.29} \\
\hline Disagree & $26.5(50)^{\star}$ & & \\
\hline Total & 100 & \\
\hline
\end{tabular}

\section{Expected Cell Frequency $x^{2} t=3.841 \mathrm{P}<0.05$ (significant result)}

Table1 shows that the calculated chi square which is 23.29 is greater than the table value which is 3.841 . Hence, the result is significant. On this ground, the null hypothesis was rejected. It then implies that there is significant relationship between family psycho-social security consciousness and moral development of adolescents.

\subsection{Hypothesis Two}

There is no significant relationship between the psycho-social security of families in personal apartments and the security of families in rented apartments.

Table Two: Security in Personal and Rented Apartments.

\begin{tabular}{|c|l|c|c|}
\hline & \multicolumn{2}{c|}{ RESPONSES } \\
\hline S/N & ITEMS & AGREE & DISAGREE \\
\hline 1. & $\begin{array}{l}\text { People who live in rented apartments receive help promptly than people in personal apartments } \\
\text { when there is an attack. }\end{array}$ & 62 & 38 \\
\hline 2. & $\begin{array}{l}\text { Rented apartments are not always being attacked by robbers due to the large number of people } \\
\text { living there compared to personal apartments. }\end{array}$ & 41 & 59 \\
\hline 3. & $\begin{array}{l}\text { Rented apartments, especially where there are many people, are busier than personal } \\
\text { apartments that are quiet and lonely. }\end{array}$ & 85 & 15 \\
\hline 4. & $\begin{array}{l}\text { The fence in a personal apartment that should be a plus sometimes serves as hideout for } \\
\text { robbers than where they could be seen easily. }\end{array}$ & 67 & 33 \\
\hline & Total & 255 & 145 \\
\hline
\end{tabular}

\begin{tabular}{|c|c|c|c|}
\hline & Average Observed Responses & df & X2c \\
\hline Agree & $65.75(50)^{\star}$ & \multirow{2}{*}{1} & \multirow{2}{*}{7.56} \\
\hline Disagree & $36.25(50)^{\star}$ & & \\
\hline Total & 100 & & \\
\hline
\end{tabular}

\section{Expected Cell Frequency $x^{2} t=3.841 \mathrm{P}<0.05$ (significant result)}

Table two shows that the calculated value 7.56 is greater than the table value which is 3.814 . Hence, the result is significant. Therefore, the null hypothesis was rejected. It implies that there is significant relationship between the psychosocial security of families in personal apartments and the security of families in rented apartments.

\subsection{Hypothesis Three}

There is no significant relationship between the psycho-social insecurity of families and the moral problems in Nigerian situation. 
Table 3: Families and National Insecurity Moral Problems

\begin{tabular}{|c|l|c|c|}
\hline & \multicolumn{2}{|c|}{ RESPONSES } \\
\hline S/N & ITEMS & AGREE & DISAGREE \\
\hline 1. & $\begin{array}{l}\text { Robbers have robbed a lot of houses, threatened and killed many families, breadwinners and } \\
\text { have gone away scot-free. }\end{array}$ & 88 \\
\hline 2. & Nigerian families are sometimes exposed to insecurity due to irregular power supply. & 79 & 21 \\
\hline 3. & Members of the same family sometimes threaten the safety and security of their members. & 76 & 24 \\
\hline 4. & Families where jealousy and envy thrive may have insecurity problems. & 82 & 18 \\
\hline 5. & Co -neighbours are sometimes used as agents of evil to attack the security of a family. & 86 & 14 \\
\hline 6. & $\begin{array}{l}\text { Families that allow another relation to stay with them are sometimes exposed to insecurity if } \\
\text { the person is not trustworthy. }\end{array}$ & 88 & 14 \\
\hline 7. & The achievements and wealth of a family may attract robbers to them. & 87 & 13 \\
\hline 8. & Many Nigerians may not be able to provide harm alarm to deter intruders into their homes. & 85 & 15 \\
\hline 9. & $\begin{array}{l}\text { Those who lost family members to crime, terrorism and other forms of insecurity in the land } \\
\text { suffer emotionally, morally and mentally. }\end{array}$ & 83 & 17 \\
\hline 10. & $\begin{array}{l}\text { The next door neighbours may not be trusted on the issues of security because one is not sure } \\
\text { what they are doing there. }\end{array}$ & 86 & 14 \\
\hline 11. & $\begin{array}{l}\text { Many adolescents had witnessed criminal activities and these may cause some of them to be } \\
\text { hardened to commit crimes as well. }\end{array}$ & 74 & 26 \\
\hline 12. & $\begin{array}{l}\text { Adolescents' moral behaviour may be affected by the series of insecurity in the land than the } \\
\text { adults. }\end{array}$ & 82 & 18 \\
\hline 13. & $\begin{array}{l}\text { Many adolescents who had witnessed criminal attacks against their loved ones are sometimes } \\
\text { involved in crimes to revenge. }\end{array}$ & 78 & 22 \\
\hline 14. & $\begin{array}{l}\text { Adolescents' moral development may be greatly affected because some justify why they } \\
\text { threaten the lives of others on so many grounds. }\end{array}$ & 77 & 23 \\
\hline & Total & 1151 & 249 \\
\hline
\end{tabular}

\begin{tabular}{|c|c|c|c|}
\hline & Average Observed Responses & df & X2c \\
\hline Agree & $82.4(50)^{\star}$ & \multirow{2}{*}{1} & 42.25 \\
\hline Disagree & $17.78(50)^{\star}$ & & \\
\hline Total & 100.29 & & \\
\hline
\end{tabular}

Expected Cell Frequency $\mathrm{x}^{2} \mathrm{t}=3.841 \mathrm{P}<0.05$ (significant result).

Table 3 shows that the calculated value of 42.25 is greater than the table value which is 3.814 . This means that the result is significant. The null hypothesis was therefore rejected on this ground. It implies that there is significant relationship between the psycho-social insecurity of families and the moral problems in Nigerian situation.

\subsection{Hypothesis Four}

There is no significant relationship between counselling intervention and family psycho-social moral insecurity problems.

Table 4: Counselling Intervention and Family Insecurity Moral Problems

\begin{tabular}{|c|l|c|c|}
\hline & \multicolumn{2}{|c|}{ RESPONSES } \\
\hline S/N & ITEMS & AGREE & DISAGREE \\
\hline 1. & $\begin{array}{l}\text { Well counselled adolescents are sometimes conscious of the security of other people by not intruding } \\
\text { and disturbing the peace of the families in their communities. }\end{array}$ & 84 & 16 \\
\hline 2. & $\begin{array}{l}\text { Counselling may help the adolescents to understand why they should not justify evils on whatever } \\
\text { ground. }\end{array}$ & 97 & 03 \\
\hline 3. & $\begin{array}{l}\text { Proper counselling may change the thinking system of adolescents who had witnessed or heard about } \\
\text { attacks done on families and loved ones. }\end{array}$ & 91 & 09 \\
\hline 4. & $\begin{array}{l}\text { Adequate and regular counselling enhances the attitudes and beliefs of the adolescents because they } \\
\text { are the leaders of tomorrow. }\end{array}$ & 91 & 09 \\
\hline 5. & $\begin{array}{l}\text { Counsellors should be encouraged to do effective work in the universities because that is where } \\
\text { adolescents/young adults who are involved in insecurity activities are found. }\end{array}$ & 88 & 12 \\
\hline & Total & 451 & 49 \\
\hline
\end{tabular}




\begin{tabular}{|c|c|c|c|}
\hline & Average Observed Responses & df & X2c \\
\hline Agree & $90.2(50)^{\star}$ & \multirow{2}{*}{1} & \multirow{2}{*}{64.65} \\
\hline Disagree & $9.8(50)^{\star}$ & & \\
\hline Total & 100 & & \\
\hline
\end{tabular}

Expected Cell Frequency $x^{2} t=3.841 \mathrm{P}<0.05$ (significant result)

Table 4 shows that the calculated value of chi-square of 62.65 is greater than the table value which is 8.841 . It implies that the result is significant and so the null hypothesis was rejected. It shows that there is significant relationship between counselling intervention and family psycho-social moral insecurity problems.

\section{Discussion}

The result in Table 1 shows that there is a significant relationship between family psycho-social security consciousness and moral issues of the adolescents. Factors like inadequate moral upbringing, proper monitoring and adequate supervision on the part of the parents may lead adolescents to be involved in immoral behaviour. This finding agrees with Oyebamiji and Adekola (2008) that family has failed in its duty of producing morally sound citizens for the society. Also, Lawal (2003) observed that adolescents who are morally and spiritually mature would not join bad gangs.

The result in table 2 indicated that there is significant relationship between the psycho-social security of families in personal apartments and the security of families in rented apartments. This finding agrees with Jarrett (2000) that families mark off some physical space (personal/rented) just as families in personal apartments are exposed to insecurity problems. So, also are families in rented apartments.

The result in table 3 shows that there is significant relationship between the psycho-social insecurity of families and the moral problems in Nigerian situation. This finding agrees with Akowe (2012) who observed that insecurity is everywhere in Nigeria including individual homes. He observed that most insecurity problems are sometimes caused by the adolescents from various families across the nation.

The result in table 4 shows that there is significant relationship between counselling intervention and family psycho-social moral insecurity problems. This finding agrees with Bandura (1993) that self-efficacy helps individuals to exercise control over events in their lives. In other words, counsellors can be of help by orientating the adolescents in their cognitive process that mediates behavioural change.

\section{Counselling Interaction}

The following are the counselling interaction reviews between the counsellor (researcher) and the clients (adolescents in Nigeria context):

\subsection{Preview}

The aim of the counselling was to help the adolescents to think aright on moral issues as it affects the security of families and the part that the adolescents are playing in this perspective.

Section One. Aim- To examine the reasons why some adolescents are engaging in immoral acts that affect the security of their families.

Counsellor: You are welcome to this session. Today, we shall discuss the reasons why many adolescents are participating in crimes. (The counsellor allows the client to start mentioning the reasons as it occurs to them one after the other).

Client 1: Thank you. To me, poverty is the cause of crime and immoral acts among adolescents.

Counsellor: Kindly, explain further about what you mean by poverty. How do you measure poverty?

Client 1: Poverty can be measured by parent's social class, level of education, and career achievement.

Client 2: Poverty is the inability of the parent to provide for the needs of the children in terms of feeding, clothing and shelter. Also, the inability of the parents to provide their children qualitative education is also a sign of poverty.

Client 3: I believe poverty is when my parents cannot provide for me what my mates are having. For example, if everyone is having cell phones and my parents are unable to provide mine for me, I see that as poverty.

Client 4: For me, poverty is when one's parents stay in a particular apartment for twenty years with an increase in the number of their children, and they are not able to build their own personal house. 
Counsellor: Thank you very much. All of you are very correct. The inability of the parents to satisfy their children's physical, social, psychological, medical and emotional needs is a sign of poverty. Now that we have been able to explain the meaning of poverty, do you believe that all these reasons are enough for one to engage in armed robbery, kidnapping, ritual killing and others.

Client 1: Though poverty is an issue, I don't think adolescents should use that as an excuse to steal, to kill and kidnap. There are little things that could be done legally that will earn one some money to supplement the parent's meagre resources.

Client 2: For me, some poor parents encourage their children to steal. They justify this by saying that the rich are wasteful and that nature will not be annoyed if some of the personal belongings of the rich are stolen. Since some adolescents are not condemned by their parents, they may feel that what they are doing is right and just.

Client 3: Some adolescents believe that many rich people today cheated their ways through. Therefore, they do not see why they should be hindered from cheating their ways through as well.

Client 4: For me, poverty should not be an excuse to perpetuate evils. It is an avenue to look inwards and find out the root cause of poverty in my family. The reason must be dealt with so that an end can be put to poverty in my generation.

Counsellor: You have all spoken well. Poverty can be dealt with through proper and adequate education, right attitude to life, high self-efficacy and believing in your worth.

The interaction between the Counsellor and the Client was to enable us understand the adolescent's perception of poverty and social vices.

\section{Recommendation}

The matter of security is a concern to everyone. The attempt to control insecurity activities that affect lives and property require concerted efforts from every member of the family. Based on the findings of the study, the following recommendations were made:

1. Families should create a loving atmosphere for adolescent to grow and adequate instructions with good examples from parents have a way of influencing the moral training of adolescent children.

2. Every member of the family should be taught security consciousness such as:

- Locking the door when in or out

- Not creating opportunity for criminals.

- Not opening the door for strangers.

- Not advertising one's absence when on a journey or holiday.

3. Families should endeavour to put some security measures in place like :

- home alarms

- camera spy

- camera surveillance

- Security dogs

- Security guards.

4. Family information should be kept intact within the family. Care should be taken not to talk about sensitive, personal, or business matters in public. All children in the family should be counselled to keep the family matters secret.

\section{Conclusion}

The family as an important organ of the society requires adequate security. In the Nigerian context, many families are faced with a lot of psycho-social security challenges. Apparently, no one is free from psycho-social family security problems. Various criminals such as armed robbers, kidnappers, burglars, ritual killers, suicide bombers, terrorists and others have continued to threaten the lives and security of every Nigerian. Properties have been wantonly destroyed irremediably. An average Nigerian today lives in fear.

The security situation in Nigeria today requires an urgent attention. Counselling the young ones appropriately may help in reducing this aberration in our society. Counselling goes a long way in educating the adolescents that the security of the nation is the civic duty of everyone.

Counselling would also encourage the adolescents to respect human dignity and human lives and property. Even 
though psycho-social security problems cannot be eradicated totally in our society, they can be reduced reasonably if all the suggestions made in this paper are considered and implemented.

\section{References}

Akowe, T. (2012). "Challenges of Security and Investment in Kaduna." The Nation. Sunday May 20 p. 20.

Burton, L.M. \& Jarret, R.L. (2000). "The Place of Family in Urban Neighbourhood and Child Development." Research Journal of Marriage and Family. 62(4) 1114-35.

Casper, Lynne M. and Suzanne M. Bianchi (2002). Continuity and Change in the American Family. California: Thousand Oaks.

Cormier S. \& Cormier, B. (1998. Interviewing Strategies for Helpers: Fundamental Skills and Cognitive Behaviour and Intervention. Canada: Brooks Cole.

Gibbs, J.C. (2003). "Moral Development and Reality." CA: Sage.

Lamanna, M .A \& Reiedmnna, A. (2003) Marriage and Family: Making Choices in a Diverse Society Canada: Thomson Wadswoth.

Lawal, B.O. (2003). "Teaching Religion in Colleges and Universities." Ibadan: Stirling-Horden Publishers.

Odundayo, V.O. (2001). Modern Security Management. Lagos: Shodik.

Olarewaju, I.O. (2004). "Making Moral Education Compulsory for Adolescents." in Nwazuoke I.A. \& Bamgbose (Eds.) Contemporary Issues and Research on Adolescents. Ibadan: Royal People.

Otti, P.N. (1985). "Population and Family." Population Education Mimeograph 3.

Oyebamiji, M.A. and Adekola, G.(2008). "Enhancing National Unity through Family-life Education: Implication for Sustainable Peace in the Niger-Delta Region of Nigeria.": Ife Psychologia . 16(1) 131-140.

Stacey, Judith (1996). In the Name of the Family Rethinking Family Value in the Post-modern Age. Boston: Beacon.

Usdansky, Margaret, L. (2000)."Numbers Show Families Growing Closer as They Pull Apart." New York Times, March 8.

Walker, L. J., Pitts, R.C., Hennig, K.H., and Matsuba, M.K (1995). "Reason about Morality and Real-life Moral Problems" in M. Killen \& Hart Eds.) Morality in Everyday Life. New York: Cambridge University Press.

Whitehead, B.D. \& Popenoe D. (2001). Who Wants to Marry a Soul Mate? New Survey Findings on Young Adults' Attitudes about Love and Marriage. Piscata NJ: Rutgers University. 